Indigenizing the Anthropocene? Specifying and situating multi-species encounters. International Journal of Sociology \& Social Policy

Matthew Adams, University of Brighton

This is a pre-proof author-accepted version

Accepted for publication $4^{\text {th }}$ October 2019

Please cite as Adams, M. (forthcoming) Indigenizing the Anthropocene? Specifying and situating multi-species encounters. International Journal of Sociology E Social Policy

The current issue and full text archive of this journal will be available on Emerald Insight at: www.emeraldinsight.com/0144-333X.htm 
Indigenizing the Anthropocene?

\section{Indigenizing the Anthropocene? Specifying and situating multi-species encounters}

\section{Introduction}

'wherever it looks, social science tends to see only the social activity of humans. The agency it examines, describes, or explains is normally confined to that exercised by humans, exercised directly in the case of individuals and indirectly in the case of collective practices, institutions, or rituals. The agentic power of human-nonhuman assemblages... appears as merely an effervescence of the originary agency of persons' (Bennett, 2005, p. 455).

'at a time when human activities have become so deeply embedded in earth surface processes that even the molecular composition of the atmosphere bears our signature, the most urgent task for all fields of human endeavour is to reframe our relations to the more-than-human world' (Head, 2017, p. 55).

This article is a response to numerous recent calls to 'indigenize' and 'decolonize' the Anthropocene in the social sciences and humanities (Szerszynski, 2017; Todd, 2016). In a general sense it builds on more established scholarship arguing for a decolonizing of sociology and the sociological imagination (e.g. Connell, 2018; Savransky, 2017). It also contributes to developments in environmental sociology, where the conceptual and political value of the Anthropocene as a rapidly emerging crisis narrative have been explored (e.g. Hamilton et al., 2015; Urry, 2010); though a consideration the potential of contribution of Indigenous Knowledge is largely absent (e.g. Lidskog and Waterton, 2016; Lövbrand et al., 2015; Zinn, 2016). Some sociologists argue that the field itself, despite increasing theoretical diversity, still requires a radical overhaul to keep up with earth system science planetary-level conceptualisation of Anthropocene phenomena (e.g. Bowden, 2017). In this vein, Bowden calls for a fuller theorisation of (cosmic) temporality and complexity to better render the complex, evolving social-natural assemblages of the Anthropocene. However, even here, Indigenous Knowledge is not considered part of what "we need [for] an environmental sociology for the Anthropocene” (Bowden, 2017, p. 64).

In contrast, this paper develops a radical material and relational ontology, purposefully drawing on an Indigenous knowledge framework to challenge and extend dominant conceptualisations of the Anthropocene within a posthuman and more-than-human intellectual context. The tools suggested by Indigenous feminist scholar Zoe Todd as necessary for employing Indigenous ontologies with care and respect are utilised in developing an Anthropocene social imaginary: accounting for one's own location; engaging with specific ontologies and locally informed responses to in situ challenges; and reading and citing Indigenous scholarship. Posthuman and Māori approaches to manifold multi-species entanglements shaped by anthropogenic impacts are considered - specifically the whale and the kāuri tree - as specific and situated enactments of a radically extended relational ontology. A conceptual framework for the Anthropocene is offered that articulates surprising multi-species connections between humans, trees and whales. It is argued that in approaching the specific and situated application of Indigenous ontologies in some of their grounded everyday social complexity - the "play of forces and processes that produce particular determinate moments" (Findlay, 2000, p. 309) - there is the potential to open up the Anthropocene imaginary to a more radical and ethical relational ontology.

\section{Indigenizing the Anthropocene?}

The Anthropocene is the proposed geological epoch in which human activity has become a force of nature that radically and irrevocably alters the earth we inhabit' (Swanson et al, 
2015, p. 149). This article builds on critical engagements with the Anthropocene which consider it a productive provocation, what Donna Haraway refers to as 'staying with the trouble' (2016). The Anthropocene signifies the unprecedented influence of one species - the human - upon the survival and flourishing of life on Earth. But it can also be considered an invitation - to imagine different arrangements of human existence, in which our relationship to each other, including other forms of life, is profoundly re-evaluated. To accept the Anthropocene as an invitation means to develop narratives that are embodied and embedded in human and more-than-human relational ontologies; the intersecting, co-constitutive agency of human and non-human. It is taken up in the emergence of an interdisciplinary embrace of posthuman, more-than-human analytical frames, multi-species encounters and Indigenous knowledge (Hamilton and Taylor, 2017; Panelli, 2010). Many different logics are drawn upon to interpret and frame these encounters, including Latour's network theory (2005; e.g. Nimmo, 2011), Deleuze and Guatarri's rhizome (1987; e.g. McLeod, 2014), and Haraway's conceptualisation of companion species (2003, 2008; e.g. Lorimer, 2010). In responding as a social scientist to the implications of the Anthropocene and the huge questions it raises, it is tempting to adopt into one or more of these frameworks in the hope of broadening or deepening their analytic value. However, Indigenous feminist Red River Métis, Otipemisiwak scholar Zoe Todd offers pause for thought:
When anthropologists and other assembled social scientists sashay in and start cherry- picking parts of Indigenous thought that appeal to them without engaging directly in (or unambiguously acknowledging) the political situation, agency, legal orders and relationality of both Indigenous people and scholars, we immediately become complicit in colonial violence. When we cite European thinkers who discuss the 'more-than-human' but do not discuss their Indigenous contemporaries who are writing on the exact same topics, we perpetuate the white supremacy of the academy (Todd, 2016, p. 18).

Part of the posthuman or more-than-human turn has been a belated recognition that Indigenous knowledge offers an understanding of multi-species interdependency and emergent co-becoming of human and more-than-human life - 'the always-already existence of some forms of posthumanities' (Åsberg, 2018, p. 192). Despite enormous variety, Indigenous thought shares an understanding of human life as being an embodiment of, and embedded in, the natural world, shaped by generations of connection with place (Kawagley, 1995; McGregor, 2009). An Indigenous commitment to environmental protection of and for 'future generations' is well established and long understood to be a multi-species affair, incorporating 'plants, animals, water, and all living things' (Mankiller, 2009). There is growing attention paid to the knowledge and experience of Indigenous people in relation to climate change and associated harms (e.g. NoiseCat, 2016; Smith, 2015; King, Skipper and Tāwhai, 2008); whilst a resurgent interest in animist logic amongst sociologists, geographers and anthropologists, though fraught with the dangers of misappropriation (Luisetti, 2017), marks a 'growing affective, intellectual, and political investment in Indigenous knowledges' (Harvey, 2013, p. ii); and more attempts to learn with and from Indigenous perspectives and scholars (e.g. Country et al. 2016; Wright et al. 2012).

Attention to animism as an organizing principle is echoed in Szerszynski's assertion of the need to expand Anthropocene imaginaries to include the 'multiple narratives of Indigenous and colonized peoples' (2017, p. 254). His arguments parallels Todd's - that such perspectives have been neglected and marginalized in the rapid ascendancy of Western scientific conceptualisations of the Anthropocene, which tend to denote 'a singular geochronological story of a singular planet'; a 'falsely unified' and Eurocentric story of the Earth's transformation (ibid.). Accordingly, he champions any move to 'decolonize', 'descularize' or 'indigenize' the Anthropocene. The hope here is that such a move can 
further enliven what is being laid out as an increasingly apparent Anthropocene reality human entanglement in 'co-constitutive relationships with nature and the environment, with science and technology, and with vulnerable embodiments of both human and nonhuman kinds' (Åsberg, 2018, p. 192).

What this might mean in practice; and how an 'indigenized' Anthropocene imaginary can help us make better sense of processes underway, is considered in more detail by Todd (2015; 2016). She offers a number of 'practical tools for employing Indigenous ontologies... with care and respect' (2016), avoiding the tendency to cherry-pick noted above. These include engaging with specific Indigenous ontologies, rather than abstracting or homogenising them as 'Indigenous perspectives'; especially as they are manifest in 'locally informed responses to in situ challenges' (Todd, 2015, p. 251); and reading and citing Indigenous scholarship, rather than defaulting to Euro-Western traditions of abstract and appropriation (2016, p. 14). Though inevitably limited and partial, considering the boundaries of a journal article and my own non-Indigenous background, what follows is an attempt to utilise Todd's suggested tools, via a consideration of a Māori worldview as a 'specific twenty- first-century Indigenous knowledge articulation' (TallBear, 2011, p. 230); as it is, and might, be manifest in responding to situated 'environmental' challenges that entangle humans, whales and trees.

\section{Encountering the whale}

For posthuman scholars, attending deeply can involve being open to unexpected meetings: 'strange encounters are... key to this endeavor, a willingness to expose oneself to the unknown, to alienation' (Åsberg and Braidotti, 2018, p. 17). Strangeness here might emerge from who and what is considered as capable of meaningfully relating, and thus contributing to a radically extended notion of 'the social' (Adams, 2014), though we should be alert to the fact that 'Indigenous perceptions of whom and what contributes to a societal structure are quite different from traditional Euro-Western thought' (Watts, 2013, p. 21); so any strangeness is provincial. Whilst this unsettling is arguably at the heart of endeavours to reconceptualize agency as involving more-than and other-than human entities (Bennett, 2005); the revival of geographical anthropological interest in animism (Harvey, 2006; 2013), it is already integral to many forms of Indigenous knowledge and scholarship. In what remains of this chapter then, reflecting Todd's suggested tools, we draw on Māori scholarship and knowledge to pay attention to what might appear as strange multi-species encounters, at least to non-Māori - entangling human, tree and whale.

A Māori worldview rests on 'an intricate, connected and holistic relationship with the natural world... an interconnected relationship which has developed over thousands of years into an in-depth knowledge base' (Rodgers, 2017, p. 3; Harmsworth \& Awatere, 2013). At the root of Māori cosmology, in particular, is the understanding that 'humanity and all things of the natural world are always emerging, always unfolding' (Henare, 2001, p. 198). Māori vitalism is evident as a 'belief in an original singular source of life in which that life continues as a force that imbues and animates all forms and things of the cosmos' (Henare, 2001, p. 204). The connection between all forms of life, human and other-than-human, tangible and intangible alike (Hindle and Matthewman, 2017), are articulated though whakapapa - literally meaning 'genealogy' - a taxonomic and historical framework that includes and links 'all animate and inanimate, known and unknown phenomena in the terrestrial and spiritual worlds' (Taonui, 2011, p. 1); and traces 'the origin of the universe and the world... through a series of ordered genealogical webs that go back hundreds of generations to the beginning' (Harmsworth and Awatere, 2013, p. 274). ${ }^{1}$ Whakapapa 'maps 
relationships', whereby those relations are extended through time, place and spiritual realms (Taonui, 2011, p. 1). The centrality of whakapapa within Māori culture 'cannot be overstated', and is a fundamental articulation of the Māori relationship to land as living: 'To 'know' oneself is to know one's whakapapa. To 'know' about a tree, a rock, the wind, or the fishes in the sea is to know their whakapapa' (Robert and Wills, cited in Whitt et al. 2001, p. 708). Though only briefly introduced here, whakapapa, is a constituent part of a rich Māori worldview and conceptual framework that is already rooted in relationality and cobecoming, whereby "the identity of things in the world is not understood as discrete or independent, but emerges through, and as, relations with everything else" (Jones and Hoskins, 2016, p. 25). Like many other forms of Indigenous knowledge, it already incorporates multi-species relations within an ethics of care and responsibility; one that includes human-whale encounters in general (Rodgers, 2011); and the phenomenon of mass whale stranding in particular.

A historically and culturally significant point of contact between Māori coastal tribes and whales has been via strandings. A beached whale that has died was traditionally considered a welcome bounty. Following prayer and a naming ceremony, a whale was 'flensed'- the careful slicing and rendering of the body to remove blubber, separating it from the animal's flesh, as well as teeth, eyes and bones - to be utilised within Māori culture as tools and artefacts according to established traditions within specific communities (Tipa, 2014; Marris, 2018). Sometime whales strand in groups, and are not obviously ill or injured. As an important whale migration route for whales, the Aotearoa-New Zealand coastline has seen its fair share of mass whale strandings, but in recent years here, as elsewhere, there appears to be an unprecedented number. ${ }^{2}$ In November 2018140 pilot whales stranded on a remote beach in Aotearoa-New Zealand (Roy, 2018). In the same year, rare pygmy whales stranded in numbers on the shores of New Zealand for the first time; the largest whale stranding in Aotearoa-New Zealand's history occurred in 2017, when 400 pilot whales stranded in Golden Bay. ${ }^{3}$ Why do whales beach en masse? Marine scientists, steeped in the traditions and knowledge bases of Western science, have answered cautiously, and reports of likely causes are advanced, if at all, as isolated, speculative possibilities (e.g. BBC, 2018a; Radio New Zealand, 2018); as unrelated to human activity or a problematic ocean environment (BBC, 2018b).

Many Māori (including scientists) take a different view. In recognising that more whales are beaching and dying, 'an acute sense of grief' is reported to have been growing for some time among Māori - intimately related to the sacred significance of whales in Māori culture and history (Marris, 2018). Simply stated, 'their whale kin are sick, and trying to escape an increasingly polluted and unpredictable ocean'; they are 'fleeing' the ocean. To cite Hori Parata, an elder of the Ngatiwai iwi, whale expert, and environmental resource manager: 'Our ancestors tell us the strandings are a sign from the sea. So what is the sea telling us? We need to listen' (Roy, 2019). Whilst the harvesting of dead whales is now considered culturally legitimate, the possibility that traditional Māori understandings might help explain the causes of strandings are apparently ignored and dismissed as 'overly spiritual': 'People dismiss us when we tell them our spiritual understanding of whales - why they are beaching, why they are hurting... We are not foreigners in this land. We did not take this land off anyone else. We were not lost waiting for some bullheads to tell us what was going on' (Te Kāurinui, cited in Roy, 2019). Te Kāurinuì's comments are a specific and situated echo of Todd's experiences as an Indigenous scholar - 'Even when we are present, we are often dismissed as biased, overly emotional, or unable to maintain objectivity over the issues we present' $(2015$, p. 251). 


\section{Between the forest \& the ocean}

For a worldview premised on the vital and relational holism encapsulated by whakapapa, part of the problem in established scientific frameworks is considering a phenomenon in isolation. Making further lively more-than-human connections - between the whale and the kāuri tree - opens up the Anthropocene story. Māori worldviews vary according to one's $i$ wi but share many aspects of a cosmological whakapapa - the stories of the formation of the world, and the origin of all forms of life including the human psyche. The Māori creation story unites plants, rocks, wind, seas, animals and people in a shared genealogy, traceable back to the activities of various gods (Henare, 2001). All things of the natural world are thus related by descent; humans, plants and animals are close kin (Hall, 2013; Whitt et al. 2003). Included in these origin myths are tales of many species, including, as we have seen, the whale (Bradford, 2006); but whales and kāuri are explicitly and especially linked through whakapapa in various ways." The kāuri (Agathis australis) is a giant native conifer of Aotearoa's North Island forests. They can reach up to $50 \mathrm{~m}$ tall and live for over 2000 years. Kāuri forests are among the oldest woodlands in the world, and the kāuri tree is significant in Māori culture and history a 'centrepiece of cultural and spiritual beliefs' (Lambert et al. 2016, p. 112).

Whales and kāuri share a comparative status in their respective realms, acknowledging their physical size and presence: 'Imagine you'd stepped off a waka [large canoe] after crossing the Pacific, serenaded by singing whales, and were confronted with a six- or sevenmetre-diameter kāuri trunk. What would come to mind?' (Warne, 2014). The whale - the largest sea creature - is the 'oceanic twin' of the kāuri - the largest native tree - and both are regarded as rangatira (chiefs); as respected tupuna (ancestors) of Māori; and as taonga (treasured, sacred) species (Bradford, 2006; Jolly, 2014; Warne, 2014). According to Rodgers, one tradition 'cites Te Hāpuku as the main ancestor of whales, dolphins and seals as well as tree ferns [including kāuri] which are often known as 'ngā ika ō te ngahere' the fish of the forest (Rodgers, 2017, p. 3; Hami, 2006). A particular origin story offered by a Māori elder fascinatingly extends a whale-kāuri connection:

The Legend of the Kāuri and the Sperm Whale: In times long past a sperm whale came ashore and spoke to the kāuri. "Kāuri! Come with me to the sea, which is fresh and cool." "No!" said the kāuri. "You may like the sea but I prefer to stand here with my feet in the soil." "All right said the whale. Then let us agree to exchange our skins." So that is why the bark of the kāuri is thin and full of resinous oil... Moreover, their bark and skin show similarities of texture, while kāuri gum is like the ambergris found in the intestines of the sperm whale (cited in Shortland, 2011, p.25; see also Bradford, 2006).

The way this story - a strange encounter - frames the relationship between Parāoa and kāuri, the apparent similarity of kāuri bark and whale skin, resin and oil, kāuri gum and ambergris, deepens the whakapapa connection, and gives further meaning to kāuri as 'fish of the forest'. ${ }^{5}$

Fast forward to the present, and Kāuri forests have been substantially depleted by logging, beginning with the arrival of European Settlers in the 1700s, and rapidly escalating following colonisation - used for building properties and exported in enormous numbers (King, 2003). The vestiges of ancient kāuri forest are now further threatened by anthropogenic impact - the spread of a water and soil borne pathogen, Phytophthora taxon Agathis (PTA), commonly known as Kāuri Dieback, which threatens their extinction (Weir 
et al. 2015). Human activities are centrally implicated in the spread and incidence of the disease, which is strongly correlated with 'the transfer of contaminated soils between nurseries, recreational use of kāuri forests, and track building and maintenance practices' (Bellgard et al. 2016, p. 115; Horner et al. 2014). The pathogen first infects kāuri roots, then aggressively works its way through trunk, branches and canopy, eventually causing death (ibid). ${ }^{6}$ Intriguingly, with western science failing to find an effective remedy for Dieback to date, a Northland Māori collective, incorporating traditional knowledge experts and environmental scientists, want to explore the role that whale oil and related derivatives might have in effective treatment (Roy, 2019). Such a possibility is built on the merits of the genealogical link between the whale and the kāuri tree, as it is manifest in connected responses to anthropogenic environmental impacts. It is precisely the kind of claim that has been delegitimised in the past as mere superstition, 'a Māori hocus pocus kind of witchcraft type thing which is of no benefit [...] no use' (Mark-Shadbolt cited in Boynton, 2018).

\section{Tree talk \& whale song}

As a non-Indigenous scholar, I am fast approaching the limits of my ability to flesh out the nature of a kāuri-whale connection from a Māori perspective, and there is very little, as yet, written about it by Indigenous scholars, though there are some intriguing glimpses of whale-tree interrelatedness. In a recent news report, specifically highlighting the possible role of whale oil in curing dieback, traditional medicines expert Tohe Ashby elliptically states 'that the ideology that land-based problems are only solved on land is obsolete, and [we need] to search further' (Harrison, 2018). My intention in what follows is decidedly not to turn to natural science to somehow bestow legitimacy on Māori 'hocus pocus'; or to assume that contemporary Indigenous scholarship and scientific frameworks are mutually exclusive (Cameron, 2012). It is to touch on scientific endeavour that is also attentive to alternative conceptualisations of agency, efficacy and interdependence, extending the boundaries of human and more-than human assemblages to traverse multiple species and terrains.

The kāuri tree is recognised as a 'host species' - at the heart of a complex assemblage of at least 60 companion species above ground (Harrison-Smith, 1938; Shortland, 2011). At the subterranean level, companionship is extended via mycorrhizal networks. A mycorrhiza is a symbiosis between a plant and fungus, a form of mutualism in that each flourish thanks to the activity of the other (Pringle, 2009). As Tsing describes it:

The fungus extends its body into the host's roots to siphon off some of the plant's carbohydrates through specialized interface structures, made in the encounter. The fungus depends on this food, yet it is not entirely selfish. Fungi stimulate plant growth, first, by getting plants more water, and, second, by making the nutrients of extracellular digestion available to plants. Plants get calcium, nitrogen, potassium, phosphorus, and other minerals through mycorrhiza (Tsing, 2015, p. 138).

Mycorrhizal networks are now considered 'fundamental agents' of the emerging properties of ecosystems in their own right (Simard et al. 2012, p. 39). Mycorrhiza can connect the roots between separate plants, transferring, for example, carbon, nitrogen or phosphorous (Simard et al. 1997; Simard, 2009; Teste et al. 2009). They are also conduits for chemical compounds and electrical impulses, 'infochemicals' which traverse the soil to convey and detect warnings within and across species, help defend against threats, trade and 'lend' nutrients, help recognise kin, and drive the 'community dynamics' of forest ecosystems (Barto et al. 2012). There is now more willingness to adopt behavioural, relational and 
communication terminology within a scientific framework, and explicit acknowledgement that 'underground 'tree talk' is a foundational process in the complex adaptive nature of forest ecosystems' (Gorzelak et al. 2015). Radical developments in human understanding of interspecies communicative capacities paint a remarkably rich picture of 'tree cognition' and 'forest intelligence' (Simard, 2018); of connection and community through the air, across and under the earth. Might these capabilities extend, to other species, and even beyond the forest? Simard certainly thinks so, arguing for the existence of "collective memory-based interactions among trees, fungi, salmon, bears, and people that enhance the health of the whole forest ecosystem' in making the case for a more holistic and empathic approach to forest health (2018, p. 191).

Let's briefly approach the issue from the other direction - the communicative capacities of whales; as far as our (human) methods can apprehend them. Sound travels through water four times faster through water than air and is less attenuated, and the sounds made by cetaceans, especially those at low-frequency, many undetectable by human ear, can travel far - miles even, underwater (Whitehead and Rendell, p. 54; Tyack and Miller, 2002). In this 'fluid, three-dimensional habitat, often lacking in light, sound is an essential component of a whale's perceptual system, their hearing to map their environment and their social world... giv [ing] the animals a detailed picture of their surroundings' (Whitehead and Rendell, 2015 , p. 60). Beyond mapping and navigation, whales use elaborate, complex and dynamic vocalizations to communicate with other whales (Ritts, 2017). The function and purpose of these more complex forms of acoustic contact include expressions of association, belonging, courtship, group distinction, individuality; and even as contributing to interspecific cooperation, whereby a species of whale will engage in activities such as nursing, warning or protecting another species (Fox et al. 2017; Leung et al. 2010; Pitman et al. 2017).

The size of these underwater acoustic communication networks varies enormously depending on species and location, but they can stretch for hundreds of miles (p. 393). Research in acoustical oceanography suggests the possibility that whales communicate over even longer-distances by utilising the 'deep sound' or SOFAR channel, reflecting their ocean-spanning migratory patterns (Janick, 2005; Tsuchiya et al. 2004). ${ }^{7}$ Together, whale communicative capacities are increasingly being stated as evidence of cetacean culture and personhood (Whitehead and Rendell, 2015). Earlier in this chapter we considered anthropogenic ocean noise pollution as a significant source of cetacean stress the relevance of which deepens when we consider the centrality of acoustic communication networks (Dunlop, 2016; Ritts, 2017; Williams et al. 2014); and extend to threats to whale culture and personhood. Evidence for a worldwide decline in whale vocalization since the 1960 s has amassed in recent years, and is correlated with increases in anthropogenic ocean noise (McDonald et al. 2009; Gavrilov et al. 2011; 2012).

In sum, both whales and trees are complex entities, revealing dynamic capacities for communication across multi-species networks. As branches of science develop better understandings of whale vocalisations that traverse miles of ocean, and root systems through which trees 'can hear and even hum' are they, really, as Harvey hopes, 'proving ancient conceptions of connectedness' to which Indigenous knowledge systems are more readily attuned (2019)? Within and across inter- and multi-species contact zones, might there be points of overlap? It would be an enormous step to even ask the question of whether whales and trees communicate in some way, posing remarkable questions about strange encounters: 'What if we lived in a world where the whales sing to the trees and the trees sing back to the whale as an important nourishing element of the ecosystem? What if the changing song of the sperm whale is no longer nourishing the kāuri tree as it used to, 
depriving it of a strengthening nourishment that could possibly make it more resistant to its sickness?' (Vitale, 2019).

Such a possibility is at least implied in Māori assertions linking the shared, Anthropocene precarity of whales and kāuri trees. The equivalence of their vulnerability, inscribed in their damaged bodies, suggests a radical trans-form of corporeality. It pushes at the limits of social science conceptualisations of agency, normally tethered to human activity (Bennett, 2005). Instead it indicates a more 'distributive notion of agency' in which efficacy becomes 'a power possessed by an ontologically diverse range of actants' (Bennett, 2005, p. 446). Following Bennet, Latour and others, this framing has become increasingly familiar in the development of posthuman and more-than-human ontologies. Such findings also clearly resonate with established and in motion Māori understandings of forests and oceans, and of the animated vitality of interspecies interdependency therein.

\section{Finally: Anthropocene stories}

Addressing the relations between human and more-than-human worlds in the context of the Anthropocene is a formidable challenge for social science. A priority must be to advance a more expansive and critical version of social science in which the relations between human and more-than-human becomes much more of a central concern; but in doing so it must recognise the importance of multiple histories, knowledge systems and narratives, the marginalisation of many of which can be seen as a symptom of ecological crisis. The intention in the article has been to contribute to 'Anthropocene stories' which 'continuously highlight the multiple, interdependent relations within nature, within different forms of materiality, within technologies and within social systems, [and] the interconnections between these domains'; and in doing so 'deepens our sense of the interrelatedness between nature and society' (Lidskog and Waterton, 2018, p. 39). In doing so, it has adopted Zoe Todd's suggested tools to further indigenize the Anthropocene - though there remains much more scope to do so both theoretically and methodologically. In particular a Māori perspective has been approached as specific and situated form of Indigenous thinking 'seen as not just a well of ideas to draw from but a body of thinking that is living and practiced by peoples with whom we all share reciprocal duties as citizens of shared territories (be they physical or the ephemeral)' (Todd, 2016, p. 17). Whales and trees emerge as much more than merely 'passive objects for humans to act upon or use as tools or resources' (Mullin, 2010, p. 148); they have meaningfully lives and histories entangled with humans and others in animated multispecies worlds, 'woven through with co-forming patterns of responsiveness, attention, desire, and communication' (van Dooren \& Rose, 2016, p. 81).

None of this means we are suddenly equipped with ready responses to Anthropocene trouble; or can pinpoint what a more-than-human social theory should look like. In lieu of such certainty, in concluding a number of reflections are offered that might contribute to a sociology of human and the more-than-human entanglements as contributions to radical Anthropocene narratives. First, and this is the least developed point in this discussion, Anthropocene stories must incorporate deeper colonial histories and their legacies (Lewis and Maslin, 2015; Todd, 2016). Debates about a start-date for the origin of the

Anthropocene have accompanied the term since its inception but any move to 'decolonize' or 'indigenize' the Anthropocene must at the same time recognize the ongoing impact of colonialism in shaping specific and situated trajectories of human and more-than-human entanglements. In the example of Aotearoa-New Zealand, as elsewhere, colonial power is about dispossession - a separation of people and place, the 'environmental' effects of which still reverberate deeply (Walcott, 2017); at the root of land, resource and population loss, 
whilst also decimating established knowledge and land management practices. For many Indigenous people, dispossession has also been a dislocation of the multiple, co-constituting relations and rhythms - biological, psychological, cultural - formed between species, place and space (Donald, 2009; 2012). With the freedom to reshape the appropriated landscapes more or less as they wished, colonisers imposed their own practices on the land, according to their own worldview, wholly estranged from the experience and ethical frameworks of those they had forcibly displaced (Walcott, 2017).

Colonial power also legitimatized a temporal perspective that differentiated between colonizers - who were at an advanced stage on the linear timeline of modernity' and 'progress'; and colonized - backwards, trapped outside of modernity in cyclical stasis (Fabian, 1983): 'Thus, all non-Europeans could be considered as pre-European and at the same time displaced on a certain historical chain from the primitive to the civilized, from the rational to the irrational, from the traditional to the modern, from the magic-mythic to the scientific' (Quijano, 2000, p. 556). As the final binary in this list suggests, the colonialismmodernity temporal framing also mystified European scientific knowledge as the fount head of modernity and rationality, wholly superior to 'magic-mythic' knowledge claims further back in the timeline of universal 'progress'. A colonial temporal discourse still frames approaches to the assessment of ecological impacts. Across the globe, Indigenous knowledge is still treated with suspicion, ambivalence or outright hostility, including towards Māori (Walker et al. 2013; Watts, 2013); who are 'largely excluded from local government resource management processes and their values subordinated to those of the wider community, particularly western scientific values' (Kennedy and Jefferies, 2007, p.1). Nonetheless, recent resurgence of Indigenous knowledge, movement and scholarship, especially in the context of the climate crisis and environmentalism, suggests the fight is not lost (Mankiller, 2009). Second is a reiteration of the importance of choosing to pay greater attention to reciprocity and relatedness advocated by posthuman scholarship in developing methodologies and research agendas. This is powerfully articulated by Papaschase Cree scholar Dwayne Donald as "ethical relationality” (Donald, 2012). Echoed in Todd's emphasis on specific and situated challenges, it involves "an ethical stance that requires attentiveness to the responsibilities that come with a declaration of being in relation... an ethical imperative to acknowledge and honour the significance of the relationships we have with others, how our histories and experiences position us in relation to each other' (2012, p. 535-6).

Finally, and relatedly, opening up social science theory and method to multi-species and more-than-human world we need not be restricted to tales in which we humans are the only or main players, but can freely, if carefully, incorporate whales, trees, pathogens, ships into our assemblages (Bennett, 2005). As Anna Tsing asserts, following the trail of matsutake mushrooms:

I am not limited to tracking human relations with their favored allies... Organisms don't have to show their human equivalence (as conscious agents, intentional communicators, or ethical subjects) to count. If we are interested in livability, impermanence, and emergence, we should be watching the action of landscape assemblages. Assemblages coalesce, change, and dissolve: this $i s$ the story (2015, p. 158; emphasis in original).

Todd explicitly extends Donald's framing to a posthuman, Anthropocene context, arguing that 'his thinking serves as a powerful tool with which to examine underlying assumptions about, and responses to, human and non-human relationships in the Anthropocene'. Ethical relationality can readily be extended to 'a desire to acknowledge and honour the significance of the relationships we have with others' - both human and non-human (Todd, 2015, p. 
249). It is vital to enliven Anthropocene thinking in this way, to find 'modest examples of biocultural hope' (Kirksey and Helmreich, 2010), in rehearsals of the kind of progressive collaboration that might emerge from a recognition of indigenized Anthropocene knowledges; to reach out and in for worldviews that resonate with place and with which progressive science and humanities research can learn and collaborate; to highlight narratives which 'give life and dimension to the strategies-oppositional, affirmative, and yes, often desperate and fractured-that emerge from those who bear the brunt of the planet's ecological crises' (Nixon, 2011, p. 23). This is what it means to begin to 'decolonize' and 'indigenize' the Anthropocene (Szerszynski, 2017; Todd, 2015).

\section{References}

Adams, M. (2014). Approaching nature, sustainability and ecological crises from a critical social psychological perspective. Social and Personality Psychology Compass, 8(6), 25 1-262.

Åsberg, C. (2018). Feminist posthumanities in the Anthropocene: Forays into the Postnatural. Journal of Posthuman Studies, 1(2), 185-204.

Åsberg, C. and Braidotti, R. (2018) Feminist posthumanities: An introduction. In C. Åsberg and R. Braidotti (eds.) A feminist companion to the posthumanities. New York: Springer. Pages $1-22$.

Barto, E. K., Weidenhamer, J. D., Cipollini, D., \& Rillig, M. C. (2012). Fungal superhighways: do common mycorrhizal networks enhance below ground communication? Trends in Plant Science, 17(11), 633-637.

BBC (2018a) Whales stranded in New Zealand: Another 50 pilot whales die. BBC News Accessed 12 April 2019 https://www.bbc.co.uk/news/world-asia-46395410

BBC (2018b) Hamelin Bay: Nearly 150 beached whales die in Australia. BBC Nerws 23 March 2018. Accessed 12 April 2019 https://www.bbc.co.uk/news/world-australia$\underline{43519439}$

Bennett, J. (2005). The agency of assemblages and the North American Blackout. Public Culture, 17(3), 445-65.

Boynton, J. (2018) Boost in funding for Kāuri dieback, myrtle rust research, Radio New Zealand November 20 2018. Accessed 12 April 2019

https://www.radionz.co.nz/news/national/376388/boost-in-funding-for-kāuri-diebackmyrtle-rust-research

Bradford H., (2006) Te whānau puha - whales - Whales in Māori tradition. Te Ara. Encyclopedia of New Zealand. Accessed 9 February 2019 http://www.TeAra.govt.nz/en/tewhanau-puha-whales/page-1

Cameron, E. S. (2012). Securing Indigenous politics: A critique of the vulnerability and adaptation approach to the human dimensions of climate change in the Canadian Arctic. Global Environmental Change, 22(1), 103-114. 
Country, B., Wright, S., Suchet-Pearson, S., Lloyd, K., Burarrwanga, L., Ganambarr, R., Ganambarr-Stubbs, M., Ganambarr, B., Maymuru, D. and Sweeney, J., 2016. Co-becoming Bawaka: Towards a relational understanding of place/space. Progress in Human Geography, 40(4), 455-475.

Cressey, J. (1998). Making a splash in the Pacific: Dolphin and whale myths and legends of Oceania. Rapa Nui Journal, 12, 75-84.

Donald, D. (2009). Forts, Curriculum and Indigenous Métissage: Imagining Decolonization of Aboriginal-Canadian Relations in Educational Contexts. First Nations Perspectives, 2(1), 124.

Donald, D. (2012). Indigenous Métissage: A decolonizing research sensibility. International Journal of Qualitative Studies in Education, 25(5), 533-555.

Deleuze, G., \& Guattari, F. (1987). A thousand plateaus: Capitalism and schizophrenia. London: Bloomsbury Publishing.

Dunlop, R. A. (2016). The effect of vessel noise on humpback whale, Megaptera novaeangliae, communication behaviour. Animal Behaviour, 11 1, 13-21.

Fabian, J. (1983). Time and the other: How anthropology makes its object. New York: Columbia University Press.

Fox, K. C., Muthukrishna, M., \& Shultz, S. (2017). The social and cultural roots of whale and dolphin brains. Nature Ecology \& Evolution, 1(11), 1699.

Gavrilov, A. N., McCauley, R. D. \& Gedamke, J. (2012) Steady inter and intra-annual decrease in the vocalization of Antarctic blue whales. Journal of the Acoustical Society of America, 131, 4476-4480.

Gavrilov, A. N., McCauley, R. D., Salgado-Kent, C., Tripovich, J. \& Burton, C. (2011) Vocal characteristics of pygmy blue whales and their change over time. J. Acoust. Soc. Am. 130, 3651-3660.

Gerth, M. (2017) Preventing a fatal attraction: disrupting the spread of kāuri dieback disease. Lecture at the first national meeting of the New Zealand Biological Heritage Ng Koiora Tuku Iho National Science Challenge. Accessed 12 April 2019 https://www.youtube.com/watch? v=BYNcDPEuhbI

Gorzelak, M. A., Asay, A. K., Pickles, B. J., \& Simard, S. W. (2015). Inter-plant communication through mycorrhizal networks mediates complex adaptive behaviour in plant communities. AoB PLANTS, 7, plv050, 1-13.

Hall, M. (2013) Talk among the trees: animist plant ontologies and ethics. In G. Harvey (ed.) The handbook of contemporary animism. London: Routledge, pp. 385-394.

Hamilton, L., \& Taylor, N. (2017). Ethnography after humanism: Power, politics and method in multi-species research. New York: Springer.

Hanson, A. (1989). The making of the Māori: Culture invention and its logic. American Anthropologist, 91(4), 890-902. 
Haraway, D. (2016) Staying with the trouble. Minneapolis: University of Minnesota Press.

Haraway, D. (2008). When species meet. Minneapolis: University of Minnesota Press.

Harrison-Smith, J. (1938) The Kāuri as a host tree. New Zealand Journal of Forestry, 4(3), 173-177.

Harrison, R. 2018 Potential whakapapa Māori solution for kāuri dieback outbreak. Te Ao Māori News. Tuesday 22 May 2018. Accessed 13 April 2019 https://www.maoritelevision.com/news/regional/potential-whakapapa-maori-solutionkāuri-dieback-outbreak

Harvey, B. (2019) Death of the gods: The woeful response to kāuri dieback disease. Noted. 21 February 2019. Accessed 13 April 2019 https://www.noted.co.nz/planet/kāuri-diebackdisease-auckland-woeful-response/

Harvey, G. (ed.) (2013) The handbook of contemporary animism. London: Routledge

Head, L. (2016). Hope and grief in the Anthropocene: Re-conceptualising human-nature relations. London: Routledge.

Harmsworth, G. R., \& Awatere, S. (2013). Indigenous Māori knowledge and perspectives of ecosystems. Ecosystem services in New Zealand — conditions and trends. Manaaki Whenua Press, Lincoln, New Zealand, 274-286.

Henare, M (2001) Tapu, Mana, Mauri, Hau, Wairua. A Māori philosophy of vitalism and cosmos. In: J.A. Grimm (ed.) Indigenous traditions and ecology, The interbeing of cosmology and community. Cambridge, MA: Harvard University Press, pp. 197-221.

Hindle, R., \& Matthewman, S. (2017). Māori literacies: Ecological perspectives. Set: Research information for teachers, 3, 32-37.

Horner, I. J., Hough, E. G., \& Zydenbos, S. M. (2014). Pathogenicity of four Phytophthora species on kāuri: In vitro and glasshouse trials. New Zealand Plant Protection, 67, 54-59

Janik, V. M. (2005). Underwater acoustic communication networks in marine mammals. In McGregor, P. K. (Ed.). Animal communication networks. Cambridge: Cambridge University Press, pp. 390-415.

Jones, A. \& Hoskins, T.K. (2016). A mark on paper: The matter of Indigenous-settler history. In C. Taylor \& C. Hughes, (Eds.) Posthuman research practices in education. London: Palgrave Macmillan,

Kawagley, A. O. (1995). A Tupiaq worldview: A pathway to ecology and spirit. Prospect Heights: Waveland Press.

Kennedy, N., \& Jefferies, R., (2007). The PUCM Kaupapa Māori environmental outcomes and indicators model. University of Waikato: Hamilton, New Zealand.

King, M. (2003). The Penguin history of New Zealand. Harmondsworth: Penguin. 
King, D. N. T., Skipper, A., \& Tawhai, W. B. (2008). Māori environmental knowledge of local weather and climate change in Aotearoa-New Zealand. Climatic Change, 90(4), 385.

Kirksey, S. E. \& Helmreich, S. (2010). The emergence of multispecies ethnography. Cultural anthropology, 25(4), 545-576.

Lambert S., Waipara N., Black A., Mark-Shadbolt M., Wood W. (2018) Indigenous Biosecurity: Māori Responses to Kāuri Dieback and Myrtle Rust in Aotearoa New Zealand. In: Urquhart J., Marzano M., Potter C. (eds.) The Human Dimensions of Forest and Tree Health. Palgrave Macmillan, Cham.

Lattimore, R. (2013) The New Zealand Economy: An Introduction. Auckland: Auckland University Press.

Latour, B. (2005) Reassembling the Social: An Introduction to Actor-Network-Theory. Oxford: Oxford University Press.

Lawrence, S.A., Armstrong, C.B., Patrick, W.M. and Gerth, M.L. (2017) High-throughput chemical screening identifies compounds that inhibit different stages of the Phytophthora agathidicida and Phytophthora cinnamomi life cycles. Frontiers in Microbiology, doi: 10.3389/fmicb.2017.01340.

Lidskog, R. \& Waterton, C. (2018) The Anthropocene: Its conceptual usage and sociological challenges, pp. 25-46 in Boström, M. and Davidson, D. (eds) Environment and Society: Concepts and Challenges. Basingstoke: Palgrave. DOI: 10.1007/978-3-319-76415-3

Lewis, S. and Maslin, M. (2015) Defining the Anthropocene. Nature, 519(7542), 171. https://www.nature.com/articles/nature 14258

Leung, E. S., Vergara, V., \& Barrett-Lennard, L. G. (2010). Allonursing in captive belugas (Delphinapterus leucas). Zoo biology, 29(5), 633-637.

Lorimer, J. (2010). Elephants as companion species: The lively biogeographies of Asian elephant conservation in Sri Lanka. Transactions of the Institute of British Geographers, 35(4), 491-506.

Mankiller, W. (2009) Being Indigenous in the $21^{\text {st }}$ century. Cultural Survival Quarterly, 33-1 A Celebration of Pacific Culture. Accessed 3 March 2019 https://www.culturalsurvival.org/publications/cultural-survival-quarterly/beingIndigenous-21st-century

Marris, E. (2018) This man has helped give 460 dead whales a second life - as art. National Geographic, April 9, 2018. Accessed February 8, 2019

https://news.nationalgeographic.com/2018/04/new-zealand-Māori-beached-whalesflensing/

Mcdonald, M. A., Hildebrand, J. A. \& Mesnick, S. (2009) Worldwide decline in tonal frequencies of blue whale songs. End Species Res. 9, 13-21. 
McGregor, D., 2009. Linking traditional knowledge and environmental practice in Ontario. Journal of Canadian Studies 43, 69-100.

McLeod, K. (2014). Orientating to assembling: Qualitative inquiry for more-than-human worlds. International Journal of Qualitative Methods, 13(1), 377-394.

Mullin, M. (2010). Anthropology's animals. In M. DeMello (Ed) Teaching the Animal: Human-Animal Studies Across the Disciplines. New York: Lantern Books, pp. 145-201.

Nimmo, R. (2011). Actor-network theory and methodology: Social research in a more-thanhuman world. Methodological Innovations Online, 6(3), 108-1 19.

Nixon, R. (2011). Slow Violence and the Environmentalism of the Poor. Harvard University Press.

NoiseCat, J. B. (2016). Slaying the Carbon-Consuming Colonial Hydra: Indigenous Contributions to Climate Action. Development, 59(3-4), 199-204.

Panelli, R. (2010). More-than-human social geographies: Posthuman and other possibilities. Progress in Human Geography, 34(1), 79-87.

Pitman, R. L., Deecke, V. B., Gabriele, C. M., Srinivasan, M., Black, N., Denkinger, J., Schulman-Janiger, A. (2017). Humpback whales interfering when mammal-eating killer whales attack other species: Mobbing behavior and interspecific altruism? Marine Mammal Science, 33(1), 7-58.

Pringle, A. (2009). Mycorrhizal networks. Current Biology, 19(18), R838-R839.

Project Jonah (n.d.) Why whales strand. Accessed February 122019 https://www.projectjonah.org.nz/Stranded+dolphins++whales/Why+Whales+Strand.ht $\underline{\mathrm{ml}}$

Quijano, A. (2000) Coloniality of Power, Eurocentrism, and Latin America. Nepantla: Views from South 1(3): 533-580. Accessed https://www.decolonialtranslation.com/english/quijanocoloniality-of-power.pdf

Radio New Zealand, 2018 New Zealand beached whales: Why are so many getting stranded? December 1 2018. Radio New Zealand. Accessed

https://www.radionz.co.nz/news/national/377272/new-zealand-beached-whales-why-areso-many-getting-stranded

Ritts, M., 2017. Amplifying environmental politics: Ocean noise. Antipode, 49(5), pp.14061426.

Rodgers, 2017 The connection of Māori to whales. Unpublished Masters thesis, University of Canterbury. Christchurch, New Zealand. Accessed here https://ir.canterbury.ac.nz/handle/10092/14087

Roy, E.A. (2019) 'What is the sea telling us?’ Māori tribes fearful over whale strandings 
January 3 2019. The Guardian. Accessed

https://www.theguardian.com/environment/2019/jan/03/what-is-the-sea-telling-usmaori-tribes-fearful-over-whale-strandings

Roy, E.A. (2018) More than 140 pilot whales die in 'heartbreaking' New Zealand stranding. 26 November 2018The Guardian. Accessed 13 April

https://www.theguardian.com/environment/2018/nov/26/more-than-140-pilot-whalesdie-in-heartbreaking-new-zealand-stranding

Shortland, T. (2011). Cultural indicators for Käuri Ngahere. A report prepared for the Tangata Whenua Roopu. Kāuri Dieback Joint Agency Response. Whangarei: New Zealand.

Simard, S. W. (2009). The foundational role of mycorrhizal networks in self-organization of interior Douglas-fir forests. Forest Ecology and Management, 258, S95-S107.

Simard, S. W. (2018). Mycorrhizal networks facilitate tree communication, learning, and memory. Memory and Learning in Plants, 191-213.

Simard, S. W., Beiler, K. J., Bingham, M. A., Deslippe, J. R., Philip, L. J., \& Teste, F. P. (2012). Mycorrhizal networks: mechanisms, ecology and modelling. Fungal Biology Reviews, 26(1), 39-60.

Simard, S. W., Perry, D. A., Jones, M. D., Myrold, D. D., Durall, D. M., \& Molina, R. (1997). Net transfer of carbon between ectomycorrhizal tree species in the field. Nature, 388(6642), 579 .

Smith, L. T. (2015) Kaupapa Māori research: Some Kaupapa Māori principles. In Pihama, L., Tiakiwai, S. J., \& Southey, K. (eds.). Kaupapa rangahau: A reader. A collection of readings from the Kaupapa Rangahau workshops series. Te Kotahi Research Institute: New Zealand. Pages 47-53.

Swanson, H. A., Bubandt, N., \& Tsing, A. (2015). Less than one but more than many: Anthropocene as science fiction and scholarship-in-the-making. Environment \&o Society: Advances in Research, 6(1), 149-166.

Szerszynski, B. (2017). Gods of the Anthropocene: geo-spiritual formations in the Earth's new epoch. Theory, Culture E Society, 34(2-3), 253-275.

TallBear, K. (2011) Why interspecies thinking needs Indigenous standpoints. Fieldsights, November 18. https://culanth.org/fieldsights/why-interspecies-thinking-needsIndigenous-standpoints

Taonui, R. (2011) Whakapapa - genealogy - What is whakapapa?' Te Ara Encyclopedia of New Zealand. Accessed 13 April 2019 http://www.TeAra.govt.nz/en/whakapapagenealogy/page-1

Teste, F. P., Simard, S. W., Durall, D. M., Guy, R. D., Jones, M. D., \& Schoonmaker, A. L. (2009). Access to mycorrhizal networks and roots of trees: importance for seedling survival and resource transfer. Ecology, 90(10), 2808-2822. 
Tipa, K. R. (2014) The science of standings, Te Rūnanga o Ngāi Tahu, 21 December 2014. Retrieved https://ngaitahu.iwi.nz/our_stories/science-strandings/

Todd, Z. (2015). Indigenizing the Anthropocene. In H. Davis \& E. Turpin (Eds.), Art in the Anthropocene: Encounters Among Aesthetics, Politics, Environments and Epistemologies. London: Open Humanities Press, pp. 241-254.

Todd, Z. (2016). An Indigenous feminist's take on the ontological turn: "Ontology" is just another word for colonialism. Journal of Historical Sociology, 29(1), 4-22.

Tsing, A. L. (2015). The mushroom at the end of the world: On the possibility of life in capitalist ruins. Princeton, New Jersey: Princeton University Press.

Tsuchiya, T., Naoi, J., Futa, K., \& Kikuchi, T. (2004). Difference in simulated low-frequency sound propagation in the various species of baleen whale. Japanese Journal of Applied Physics, 43(5S), 3193.

van Dooren, T., \& Rose, D. B. (2016). Lively ethography Storying animist worlds. Environmental Humanities, 8(1), 77-94.

Vitale, S. (2017) Of whales \& trees. http://thesoundhealer.org/of-whales-and-trees-soundecology/

Walker, S., Eketone, A., \& Gibbs, A. (2006). An exploration of kaupapa Māori research, its principles, processes and applications. International Journal of Social Research

Methodology, 9(4), 331-344.

Walcott, S. J. (2017) From the darkness. In Dark Mountain Project collective (eds.) Dark Mountain Project, Issue 12 (Sanctum), pp. 11-22.

Watts, V. (2013). Indigenous place-thought \& agency amongst humans and non-humans (First Woman and Sky Woman go on a European world tour!). Decolonization: Indigeneity, Education E Society, 2(1), 20-34

Warne, K. (2014). Talking with trees. New Zealand Geographic. Issue 128, July-August 2014. Accessed 13 April 2019 https://www.nzgeo.com/stories/talking-with-trees/

Whitehead, H., \& Rendell, L. (2014). The cultural lives of whales and dolphins. Chicago: University of Chicago Press.

Whitt, L. A., Roberts, M., Norman, W., \& Grieves, V. (2001). Belonging to land: Indigenous knowledge systems and the natural world. Okla. City UL Rev., 26, 701-722.

Williams, R., Clark, C. W., Ponirakis, D., \& Ashe, E. (2014). Acoustic quality of critical habitats for three threatened whale populations. Animal Conservation, 17(2), 174-185.

Wright, S., Lloyd, K., Suchet-Pearson, S., Burarrwanga, L., Tofa, M., \& Country, B. (2012). Telling stories in, through and with Country: engaging with Indigenous and more-thanhuman methodologies at Bawaka, NE Australia. Journal of Cultural Geography, 29(1), 39-60. 
1 There are obvious problems translating Māori terms into English and retaining their meaning outside of their original context. Where possible here, definitions and meanings are drawn from Māori scholarship. ${ }^{2}$ Aotearoa is the Māori name for New Zealand. It is now common practice to refer to both names together. See https://sayit.co.nz/blog/aotearoa-new-zealand

3 'Although hundreds of locals participated in a mass civilian rescue effort, more than 300 whales died' https://www.theguardian.com/world/2017/feb/10/hundreds-whales-die-mass-stranding-new-zealand-beach

See also https://www.bbc.co.uk/news/av/world-43521353/over-100-whales-die-in-mass-stranding-in-australia 4. Tales of 'partnerships existing between creatures of the sea and 'guardian' plants on the land', including whales and large trees (Cressey, 1998, p. 81-2), appear regularly in Indigenous legends and stories (Harvey, 2019).

${ }^{5}$ In a further parallel, kāuri gum, a resin, like whale oil and ambergris, became an important export in the colonial and early industrial era (Lattimore, 2013).

${ }^{6}$ According to a recent news report, the pathogen 'can sense a kāuri tree's roots, and swim towards them to cause infection' (Smith, 2018); a point that seems to be supported by microbiologist Monica Gerth, who investigates how disease-causing microbes move, 'smell' and communicate: 'One key to the devastating spread of soil-borne Phytophthora are free-swimming cells, called zoospores. Zoospores swim through water-logged soils, and once a zoospore finds a host plant, it encysts on the root and initiates the infection. Our idea is that the spread of kāuri dieback can be mitigated by disrupting the ability of zoospores to 'smell' and navigate towards their host plants. (Gerth, 2017; Lawrence et al. 2017).

7 The deep channel is a layer 600-1200m below the surface in which sound is trapped and travels almost horizontally, with much less transmission loss' (Janick, 2005, p. 397).

\section{About the author}

Matthew Adams is Principal Lecturer in the School of Applied Social Science, at the University of Brighton, UK. His research interests are the social, political, cultural and psychological dimensions of human-nature and multi-species relations, climate crisis and the Anthropocene. His most recent book was Ecological Crisis, Sustainability and the Psychosocial Subject: Beyond Behaviour Change (2016, Palgrave). His next book, Anthropocene Psychology: Being Human in a More-than-Human World, will be published by Routledge in 2020. Matthew Adams can be contacted at: ma21@brighton.ac.uk 